\title{
Fasciola hepatica: An assessment on the vectorial capacity of Radix labiata and $R$. balthica commonly found in Belgium
}

\author{
Y. Caron *, S. Lasri, B. Losson \\ Department of Infectious and Parasitic Diseases, Faculty of Veterinary Medicine, University of Liège, B-4000 Liège, Belgium \\ Received 23 May 2007; received in revised form 28 June 2007; accepted 6 July 2007
}

\begin{abstract}
A previous study conducted in Belgium revealed that genetic material of Fasciola sp. was present in snail species belonging to the genus Radix. Here, these snails were collected and identified by DNA-based techniques as Radix labiata and Radix balthica. These two species and Galba truncatula (the major intermediate host in Europe) were experimentally infected with Fasciola hepatica. The resulting metacercariae were fed to rats and the infection was monitored using several techniques. Microscopy revealed the presence of larval stages in 78.3, 45, and $6.25 \%$ of $G$. truncatula, $R$. labiata, and $R$. balthica snails, respectively. These results were confirmed by a PCR that amplifies a Fasciola sp. specific sequence. Furthermore, this PCR was found to be more sensitive than microscopic examination. R. labiata shed fewer metacercariae than G. truncatula but these were as infective to rats as those shed by $G$. truncatula. This study demonstrates that $R$. labiata may act as an incidental intermediate host for $F$. hepatica in Belgium.
\end{abstract}

(C) 2007 Elsevier B.V. All rights reserved.

Keywords: Fasciola hepatica; Lymnaeidae; Polymerase chain reaction (PCR); Vectorial capacity; Microscopy; Second internal transcribed spacer (ITS-2)

\section{Introduction}

Fasciolosis is a food-borne trematode infection, which has a worldwide distribution. It is responsible for marked economic losses in livestock due to reduced weight gain, milk production, fertility, and condemnation of livers (Genicot et al., 1991). The parasite is prevalent in Europe and a recent study from Belgium reported that $17.3 \%$ of cattle were serologically positive (Lonneux et al., 2000). This is a vectorial disease transmitted by freshwater snails of the family Lymnaeidae (Mollusca: Gastropoda: Basommatophora) (Boray, 1982; Malek, 1984). In Europe, the principal

\footnotetext{
* Corresponding author. Tel.: +32436640 98; fax: +3243664022. E-mail address: ycaron@ulg.ac.be (Y. Caron).
}

intermediate host for Fasciola hepatica is Galba truncatula O.F. Müller, 1774.

While the morphological identification of $G$. truncatula is quite easy, other lymnaeids belonging to the genus Radix Montfort, 1810 are more difficult to identify morphologically (Mas-Coma, 2005; Pfenninger et al., 2006) except for Radix auricularia auricularia Linnaeus, 1758. The analysis of nuclear ribosomal DNA ITS-2 sequences has been used for the identification of the different species (Bargues et al., 2001; Mas-Coma et al., 2005). Several authors (Bank et al., 2002) have reported the presence of the following species of the genus Radix in Belgium: $R$. auricularia auricularia, Radix labiata, Rossmässler, 1835, and Radix balthica Linnaeus, 1758. During a previous research programme dedicated to the study of biodiversity in small water surfaces in Belgium, several Radix spp. were collected and examined at our 
laboratory. A specific Fasciola DNA sequence was amplified by polymerase chain reaction (PCR) according to Kaplan (Kaplan et al., 1995). The study revealed that specific DNA material was present in adult Radix spp. (Caron, 2004).

Microscopic examination is the most frequently used technique to detect $F$. hepatica in the intermediate host. Historically, three approaches have been used to diagnose trematode infections in snails: (1) observation of cercarial shedding, (2) dissection and (3) crushing, followed by microscopic examination (Kaplan et al., 1997). Although those techniques are simple, fast, and very cheap, they have low sensitivity and/or specificity. Indeed, prior to the release of rediae from the sporocyst, and their subsequent migration through the tissue of the snail (around day 21 post-infection), the detection of the parasite is difficult. Nevertheless, young rediae might be seen 9-10 days after infection. Before cercarial development, however, the intra-molluscan stages of the different trematode species are difficult to differentiate (Kaplan et al., 1995). For this reason, several DNA- or RNA-based techniques were developed (Shubkin et al., 1992; Rognlie et al., 1994; Kaplan et al., 1995; Kramer and Schnieder, 1998; Mostafa et al., 2003; Magalhaes et al., 2004; Cucher et al., 2006). These techniques are specific and sensitive (Kaplan et al., 1997) but are rarely used to detect naturally occurring infections, although this should be one of their main applications. They would be suitable, for example, for monitoring seasonal transmission during epidemiological studies (Rognlie et al., 1994; Kaplan et al., 1997).

The present study was aimed at the molecular identification of two populations of snails belonging to the genus Radix and commonly found in Belgium. Furthermore, the vectorial capacity of these species for $F$. hepatica was evaluated under experimental conditions. Infection of the snails was monitored using a microscopic examination and a PCR technique. Finally, the infectivity of the different populations of metacercariae was evaluated in an experimental model of infection in rats.

\section{Materials and methods}

\subsection{Snails}

G. truncatula was used as a positive control. The colony originated from a French population $\left(46^{\circ} 40^{\prime} 34.81^{\prime \prime} \mathrm{N}\right.$ and $\left.1^{\circ} 22^{\prime} 58.58^{\prime \prime} \mathrm{W}\right)$, living in the commune of Migné, department of Indre. This population was used because past experimental infections proved that this population was highly susceptible to $F$. hepatica (Vignoles et al., 2001). Radix sp. 1 and Radix sp. 2 were collected from the field in 2 locations in Belgium. Radix sp. 1 was collected in the commune of Ernonheid $\left(50^{\circ} 23^{\prime} 45.86^{\prime \prime} \mathrm{N}\right.$ and $\left.5^{\circ} 40^{\prime} 43.79^{\prime \prime} \mathrm{E}\right)$ and Radix sp. 2 in Sart Tilman $\left(50^{\circ} 34^{\prime} 51.03^{\prime \prime} \mathrm{N}\right.$ and $\left.5^{\circ} 35^{\prime} 43.17^{\prime \prime} \mathrm{E}\right)$ respectively, Province of Liège. The coordinates were calculated with Google Earth (version 4, Mountain View, CA, USA).

\subsubsection{Snail identification}

The ITS-2 region sequence was analysed according to Bargues and Mas-Coma (2005). The snail DNA was extracted from half of the foot using a commercially available kit (High Pure PCR Template Preparation Kit, Roche) and DNA concentration was measured with a spectrophotometer (Nanodrop, Wilmington, DE, USA). The ITS-2 sequence was amplified by PCR using a commercial PCR kit (Core System 1, Promega Benelux, Leiden, The Netherlands). The primers used were News2 (sense) 5'-TGT-GTC-GAT-GAA-GAA-CGCAG-3' and Its2Rixo (antisense) 5'-TTC-TAT-GCTTAA-ATT-CAG-GGG-3' (Almeyda-Artigas et al., 2000; Bargues et al., 2001). Amplification was performed in a total volume of $100 \mu \mathrm{l}$. The PCR mixture was prepared according to the manufacturer's recommendations and $200 \mathrm{ng}$ of template DNA was added. Amplification was performed in a Peltier Thermal Cycler (MJ Research, Biozym, Landgraaf, Belgium) with an initial denaturation step at $94{ }^{\circ} \mathrm{C}$ for 2 min, followed by 35 denaturation cycles at $94{ }^{\circ} \mathrm{C}$ for $30 \mathrm{~s}$, annealing at $54{ }^{\circ} \mathrm{C}$ for $30 \mathrm{~s}$ and extension at $72{ }^{\circ} \mathrm{C}$ for $30 \mathrm{~s}$ followed by a final extension at $72{ }^{\circ} \mathrm{C}$ for $7 \mathrm{~min}$. The amplification products were electrophoretically resolved in $1 \%$ agarose gels and stained with ethidium bromide. The DNA strips were cut and then purified with a kit (Geneclean, MP Biomedicals, Brussels, Belgium) and sequenced with a genetic analyser (ABI PRISM $^{\circledR}$ 3100, Applied biosystem, Lennik, Belgium). The ITS-2 sequences obtained were compared with the BLASTn genomic database (Altschul et al., 1997) and those presenting the higher identity was consider as the most probable identification.

\subsubsection{Snail breeding}

The three snail species were maintained in the laboratory for breeding. Briefly, snails were kept on plastic dishes (G. truncatula and Radix sp. 2) or in aquaria (Radix sp. 1) to minimize their motality rate, in an air-conditioned room (PVG, Schoten, Belgium), under the following conditions: constant temperature of $20{ }^{\circ} \mathrm{C}$, diurnal photophase of $12 \mathrm{~h}$ with a light intensity 
of 3000-4000 lux. They were fed with leaves of pesticide free lettuce and left for 5 days in standing spring water (Romy Spring) before use (Van der Steen et al., 1969). Plastic dishes and aquaria were checked every day and rinsed every week. Dead snails were removed daily.

\subsection{Rats}

Eighteen 15-week-old female Wistar rats were used (University of Liège breeding unit). All animals were individually marked, housed in conventional cages with grid floors, and fed a commercial rodent diet ad libitum for the entire experiment (Prestige, Versele-Laga, Belgium).

\subsection{Parasites}

Eggs of $F$. hepatica were recovered at a local slaughterhouse in Liège from the bile of infected cattle. F. hepatica eggs were incubated for 20 days at $20^{\circ} \mathrm{C}$ in complete darkness for miracidial development (Ollerenshaw, 1971).

\subsection{Experimental infections}

\subsubsection{Snail infection}

In order to compare the mortality in infected and uninfected snail populations, mortality rates in the breeding unit were calculated for each species. One hundred newly hatched uninfected snails were raised for 50 days. Dead snails and egg masses were regularly removed. At the end of the 50-day period, the remaining snails were counted.

One hundred juvenile (1-2 mm) snails of each species were used in each infection experiment as it was described in previous studies (Busson et al., 1982; Vignoles et al., 2002). Each snail was placed in one hole of a 24 well micro-plate filled with spring water. Each snail was exposed to two miracidia for $5 \mathrm{~h}$. The choice of two, rather than one, miracidia per snail was prefered because the infection rate of $G$. truncatula was higher and in $85 \%$ of infected snails, only one of the two miracidia developed (Preveraud-Sindou and Rondelaud, 1995). Thereafter the exposed snails were maintained in the breeding unit for a maximum of 50 days as described above. Twenty snails of each species were collected on days 15 and 30 post-infection (PI). On day 50, thermal shock was provoked by applying ice to the surviving snails, in order to stimulate the shedding of cercariae. Young, uninfected snails were used as negative controls.

\subsubsection{Rat infections}

Rats were divided into three groups of six animals each. Groups 1 and 2 were infected with metacercariae from the cercariae shed by G. truncatula or Radix sp. 1 respectively. Group 3 acted as negative control. Twenty 2-week-old metacaercariae were suspended in an adraganth solution (VWR, Fontenay-sous-Bois, France) and administered orally to each rat. Group 3 was given an equivalent volume of the adraganth solution.

\subsection{Monitoring of snail infection}

The experimental infection of snails with $F$. hepatica was monitored using two techniques: microscopy and specific amplification of a parasite DNA sequence.

Twenty snails collected on days 15 or 30 PI were examined by squashing and dissection. Firm pressure was applied with forceps on the upper side of the last whorl near the suture to free the intra-molluscan larvae. Snail bodies were finely dissected under a stereoscopic microscope $(\times 40)$. The larvae, if present, were examined and characterised (Augot et al., 1998).

The bodies of each batch of snails were then pooled and DNA was extracted with a commercial kit (High Pure PCR Template Preparation Kit, Roche). The DNA concentration was measured with a spectrophotometer (Nanodrop, Wilmington, DE, USA). F. hepatica DNA was amplified by Polymerase Chain Reaction (PCR) using a commercial kit (Core System 1, Promega Benelux, Leiden, The Netherlands). Primers were designed based on the DNA sequence of a $124 \mathrm{bp}$ DNA Fasciola sp. specific probe (Kaplan et al., 1995): Fsh1 (sense) 5'-GAT-CAA-TTC-ACC-CAT-TTC-CGTTAG-TCC-TAC- $3^{\prime}$ and Fsh2 (antisense) $5^{\prime}$-AAA-CTGGGC-TTA-AAC-GGC-GTC-CTA-CGG-GCA-3' .

Amplification was performed in a total volume of $50 \mu \mathrm{l}$. The PCR mixture was prepared according to the manufacturer's recommendations and $200 \mathrm{ng}$ of template DNA was added. Amplification was performed in a Peltier Thermal Cycler (MJ Research, Biozym, Landgraaf, Belgium) with an initial denaturation step at $95{ }^{\circ} \mathrm{C}$ for $5 \mathrm{~min}$, followed by 40 denaturation cycles at $95{ }^{\circ} \mathrm{C}$ for $1 \mathrm{~min}$, annealing at $56^{\circ} \mathrm{C}$ for $1 \mathrm{~min}$ and extension at $72{ }^{\circ} \mathrm{C}$ for $1 \mathrm{~min}$. The amplification products were electrophoretically resolved in $1 \%$ agarose gels and stained with ethidium bromide.

\subsection{Monitoring of rat infection}

Faecal examination, copro-antigen detection and serology were all used to monitor $F$. hepatica infection in rats. Animals were weighed and blood was collected 
from the caudal vein and centrifuged $(1000 \times g$ for $10 \mathrm{~min}$ ) before infection and weekly thereafter up to 12 weeks PI. Individual fresh stools were collected twice a week. Sera and stools were stored at $-20{ }^{\circ} \mathrm{C}$ or $4{ }^{\circ} \mathrm{C}$, respectively, prior to examination.

A standard sedimentation and flotation technique was used to analyse faecal samples. Briefly, $2 \mathrm{~g}$ of fresh faeces were mixed with $56 \mathrm{ml}$ of water and then filtered (150 $\mu \mathrm{m}$, Retsch, Aartselar, Belgium). The supernatant was centrifuged up to $1000 \times g$. The pellet was resuspended in a saturated solution of $\mathrm{ZnCl}_{2}-\mathrm{NaCl}$ and centrifuged up to $100 \times g$. The tubes were filled with the $\mathrm{ZnCl}_{2}-\mathrm{NaCl}$ solution in order to obtain an upper meniscus. A coverslip was deposited onto the meniscus. Five minutes later the coverslip was removed and examined at $\mathrm{x} 40$ for the presence of $F$. hepatica eggs. Copro-antigens were detected in $3 \mathrm{~g}$ of stools using a commercially available kit (F. hepatica Ag ELISA Kit, BIO K 201, Bio-X, Jemelle, Belgium) according to the manufacturer's instructions. This test detects excretorysecretory antigens of $F$. hepatica in the faeces of the definitive host. Specific antibody detection was based on an Enzyme-Linked-Immunosorbent-Assay (ELISA) that used somatic $F$. hepatica antigen (FhAg), as previously described (Bossaert et al., 2000). The parasites were extensively washed in phosphate buffered saline (PBS $0.05 \mathrm{M}$ ), homogenised in a Ten Broeck tissue grinder at $4{ }^{\circ} \mathrm{C}$ and sonicated. After centrifugation $\left(24,000 \times g\right.$ for $30 \mathrm{~min}$ at $\left.4{ }^{\circ} \mathrm{C}\right)$, the supernatant was collected, referred as FhAg and stored at $-20{ }^{\circ} \mathrm{C}$ until further use. Protein concentration was determined according to the Bradford protein assay. Micro-plates (Maxisorb, Greiner, Wemmel, Belgium) were coated with $100 \mu \mathrm{l}$ per well of FhAg $(10 \mu \mathrm{g} / \mathrm{ml})$ diluted in PBS, overnight at $4{ }^{\circ} \mathrm{C}$. A positive and a negative controls were included each time. Optimal antigen and conjugate concentrations were determined by checkerboard titration. After three washes in PBSTween $0.05 \%$ (PBST), the plates were saturated with a $10 \%$ powder skimmed milk solution in PBST (PBSTM) for $1 \mathrm{~h}$ at $37^{\circ} \mathrm{C}$. The plates were then washed three times in PBST and 100 fold diluted rat serum samples in PBST were added. The plates were incubated $1 \mathrm{~h}$ at $37^{\circ} \mathrm{C}$ and after three washes in PBST, a rabbit polyclonal anti-rat conjugated to horseradish peroxidase (Dako, Heverlee, Belgium) was added at a dilution of $1 / 4000$ in PBSTM. The plates were incubated $1 \mathrm{~h}$ at $37{ }^{\circ} \mathrm{C}$. After 3 washes in PBST, the 3,3'-5,5'-tetramethyl-benzidine (TMB, Fluka, Buchs, Switzerland) substrate in citrate buffer ( $\mathrm{pH}$ 4.2) with $1.5 \mathrm{ml} / \mathrm{l}$ of $\mathrm{H}_{2} \mathrm{O}_{2}(30 \%)$, was added. After $10 \mathrm{~min}$, the reaction was stopped by the addition of sulphuric acid
(1M). Optical densities (OD) were read at $450 \mathrm{~nm}$ with a microplate autoreader (Multiskan RC, Thermolabsystem, Rødovre, Denmark). The determination of the cut-off was based on the average of the OD of 70 negative reference sera plus 2 S.D.

On week 12 PI all rats were euthanasied. Postmortem examination was carried out and all flukes were collected from the bile duct and measured.

\subsection{Statistical analysis}

The results of experimental infections in the different snail species and the mortality rates between infected and uninfected snails were analyzed by Chi-square (0.05) test. A two-way analysis of variance with interaction for paired data was used to analyse the body weigh and the specific antibody response. A t test was used (0.05) to compare the number and the size of the flukes collected from the rats at post-mortem. All analyses were carried out using the SAS software (version 6.12, Cary, NC, USA).

\section{Results}

\subsection{Snails}

The ITS-2 based identification resulted in the identity of $G$. truncatula (identities $=97 \%$ ) as $G$. truncatula (Genbank accession nos. AJ243017), Radix sp. 1 (identities $=98 \%$ ) as $R$. labiata (Genbank accession nos. AJ319637) and Radix sp. 2 (identities $=97 \%$ ) as $R$. balthica (Genbank accession nos. AJ319634). Results were further confirmed by the Parasite and Vector Molecular Analysis Centre of the Department of Parasitology, University of Valencia, Spain (Bargues et al., 2001; Bargues et al., 2003; Bargues and Mas-Coma, 2005).

The mortality rates in uninfected snails were 7, 4, and $38 \%$, for G. truncatula, R. labiata, and R. balthica, respectively.

$G$. truncatula and $R$. labiata were exposed to miracidia three times while $R$. balthica was exposed twice (Tables 1 and 2). On day 15 PI, $28.3 \pm 17.5 \%$ of $G$. truncatula and $26.6 \pm 12.5 \%$ of $R$. labiata individuals showed intra-molluscan stages of F. hepatica at microscopic examination. There was no statistical difference between these two species. On day 30 PI, the mean infection rates reached $78.3 \pm 10.4$ and $45 \pm 13.2 \%$ for $G$. truncatula and for $R$. labiata respectively. These rates were significantly different $(p<0.05)$ (Tables 1 and 2). PCR performed on snails at days 15 and 30 PI confirmed the microscopic results for 
Table 1

Microscopic and PCR results on days 15 and 30 PI in Galba truncatula and Radix labiata (Radix sp. 1) experimentally infected with Fasciola hepatica

\begin{tabular}{lll}
\hline & Galba truncatula & Radix labiata \\
\hline D15 & & \\
Squashing and dissection & + & + \\
Infection rates & $28.3 \pm 17.5 \%$ & $26.6 \pm 12.5 \%$ \\
PCR & + & + \\
D30 & & \\
Squashing and dissection & + & + \\
Infection rates & $78.3 \pm 10.4 \%$ & $45 \pm 13.2 \%$ \\
PCR & + & + \\
\hline
\end{tabular}

The infection rates are the mean of 3 infestations \pm S.D. for each species.

these two species (Fig. 1). All infections in $G$. truncatula led to the shedding of cercariae $(\sim 100$ metacercariae/snail) until day 55 PI. Only one infection out of three led to the shedding of cercariae in the case of $R$. labiata ( $\sim 4$ metacercariae/snail) and no shedding was observed in the case of $R$. balthica. However, $2.5 \pm 3.5 \%$ (day $15 \mathrm{PI}$ ) and $6.25 \pm 8.8 \%$ (day $30 \mathrm{PI}$ ) of $R$. balthica snails contained $F$. hepatica larvae. PCR confirmed the results obtained by squashing and dissection. Furthermore, specific fluke DNA was amplified on day 15 PI following the first infection, whereas no intra-molluscan larvae were observed microscopically (Table 2).

The average mortality rates were calculated for each species of snail, reaching 31,25 , and $54 \%$ for $G$. truncatula, $R$. labaita, and $R$. balthica, respectively.
Table 2

Microscopic and PCR results on days 15 and 30 PI in Radix balthica (Radix sp. 2) experimentally infected with Fasciola hepatica

\begin{tabular}{lll}
\hline Infections & \multicolumn{2}{l}{ Radix balthica } \\
\cline { 2 - 3 } & 1 & 2 \\
\hline D15 & & \\
$\quad$ Squashing and dissection & $0 \%$ & + \\
Infection rates & + & + \\
PCR & & \\
D30 & - & + \\
Squashing and dissection & $0 \%$ & $12.5 \%$ \\
Infection rates & - & + \\
PCR & & + \\
\hline
\end{tabular}

The infection rates are the result of two infestations. The S.D. is 3.5 for D15 and 8.8 for D30

${ }^{\text {a }}$ Calculated on 8 individuals only.

These mortality rates were found to be statistically different to the mortality rates in uninfected snails $(p<0.05)$.

\subsection{Rats}

Body weights did not change during the course of the experimental infections (data not shown). Eggs of $F$. hepatica were observed on day 42 onwards in one rat infected with metacercariae originating from $G$. truncatula. On day 70 PI, all infected animals were passing $F$. hepatica eggs. The results of copro-antigen detection are illustrated in Fig. 2. Copro-antigen were already detectable on day 35 PI.

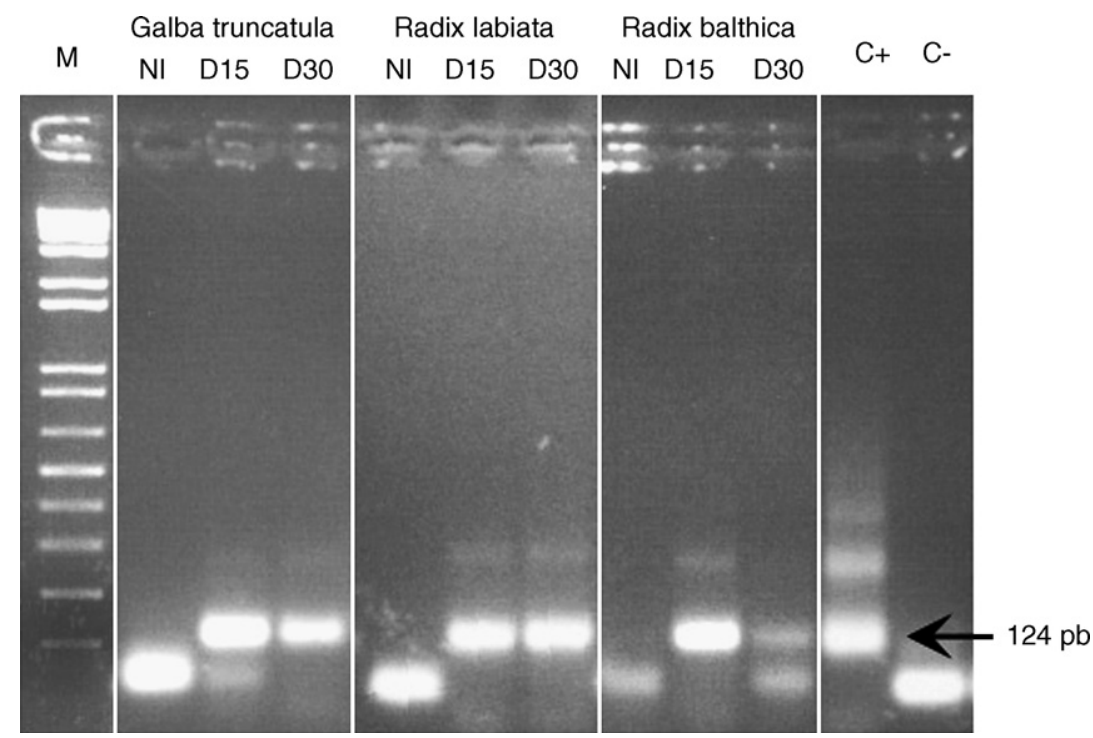

Fig. 1. Agarose gel electrophoresis following PCR performed on experimentally infected or control snails. (M) Molecular size marker DNA of 1000 bp; (NI) non-infected snails; (D15) day 15 PI; (D30) day 30 PI; (C+) positive control; (C-) negative control. 


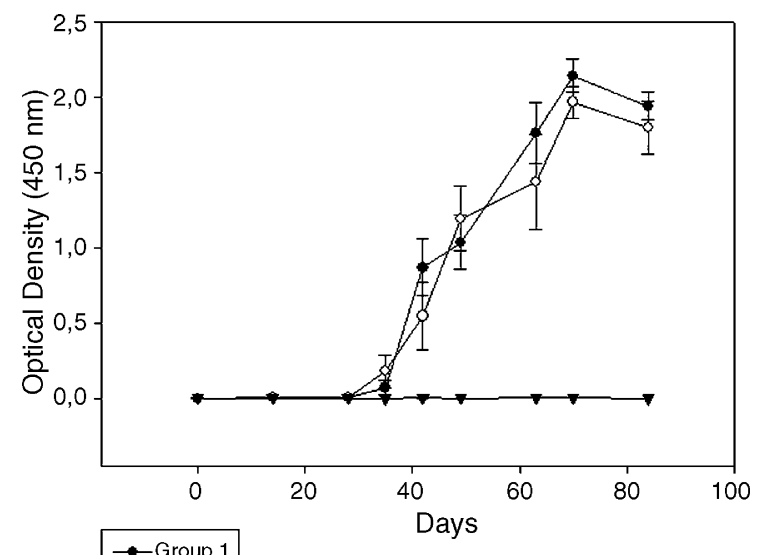

-0-Group 1

$\checkmark$ Group 3

Fig. 2. Coproantigen detection in rats experimentally infected with 20 $F$. hepatica metacercariae. Group 1-rats infected with metacercariae shed by G. truncatula; Group 2-rats infected with metacercariae shed by R. labiata (Radix sp. 1); Group 3-controls. Vertical lines represent standard errors.

There was no difference between the two groups of infected rats.

Serum antibodies to $F$. hepatica were detected by ELISA as little as 2 weeks after infection and titres remained elevated until the end of the experiment (data not shown). Again there were no statistically significant differences between the two infected groups.

At post-mortem examination, 21 and 23 flukes were collected from rats infected with metacercariae produced by $G$. truncatula $(3.5 \pm 2 / \mathrm{rat})$ and $R$. labiata $(3.8 \pm 2.7 / \mathrm{rat})$ respectively. The average size of the parasite was $2.2 \pm 0.33$ and $2.0 \pm 0.33 \mathrm{~cm}$ in flukes originating from $G$. truncatula and $R$. labiata respectively. There were no statistical differences between the number and the size of the flukes collected from the two experimental groups.

\section{Discussion}

Morphological features are not always sufficient to differentiate sibling species due to inter- and intraspecific variations. This is particularly the case for the lymnaeid snails belonging to the genus Radix (Bargues and MasComa, 2005; Pfenninger et al., 2006). Currently, their identification based on the analysis of ITS-2 DNA sequences seems to be the most reliable approach (Bargues et al., 1997, 2001, 2003; Bargues and MasComa, 1997, 2005). However, one study (Anderson, 2001) pointed out that molecular data from a single genetic marker can lead to ambiguous conclusions, which emphasizes the importance of utilizing more than one marker in studies on parasite species (Carvalho et al., 2004). For instance another marker, the Molecularly defined Operational Taxonomic Units (MOTU), inferred from mitochondrial COI sequence variation, has been shown to be congruent with biological species in the genus Radix (Pfenninger et al., 2006).

Here, the molecular identification based on ITS-2 sequence analysis led to $R$. labiata $(=R$. peregra sensu Ehrmann, 1933) for Radix sp. 1 and for R. balthica $(=R$. peregra, O.F. Müller, $1774=R$. ovata Draparnaud, 1805) for Radix sp. 2 (Bargues et al., 2001; Mas-Coma et al., 2005). It is difficult to compare these results with those obtained in previous studies based solely on morphological criteria. However, several considerations can be made:

(1) Microscopic examination was not very sensitive in determining infection status of snails. F. hepatica DNA was amplified by PCR on day 15 PI in $R$. balthica although larvae were not observed. Nevertheless, squashing and dissection are easy and cheap to perform. Furthermore, PCR was not performed on each individual snail, so the different infection rates were calculated using microscopic techniques. Therefore, considering the lack of sensitivity of microscopic examination, we only used the data recorded on day 30 PI to calculate infection rates (Kaplan et al., 1997).

(2) Experimental infection of the three snail species showed significant variation in susceptibility towards $F$. hepatica. Exposed R. labiata snails were able to harbour the parasite and allow its multiplication, leading to the shedding of infective metacercariae. The average infection rates reached 78,45 , and $6.25 \%$, for G. truncatula, R. labiata, and R. balthica, respectively. Infection rates of $67.8 \%$ have been reported for G. truncatula (Belfaiza et al., 2004). However, it must be pointed out that, in a single species, important variations exist in infection rates. For example, the infection rates of seven different populations of $G$. truncatula varied greatly, from 5 to $80 \%$ (Rondelaud et al., 2004). Furthermore, differences in susceptibility can also depend on the size of the snails (Dreyfuss et al., 1997, 2000). Only young Radix other than $R$. auricularia and its variety allow $F$. hepatica multiplication with cercariae excretion (Boray, 1969, 1978). This capacity increases with previous contacts between G. truncatula offspring and the parasite (Rondelaud, 1993).

(3) The PCR technique used in this study was found to be more sensitive than microscopic examination, especially in alternative host such as $R$. balthica. 
According to Kaplan et al. (1995), 1 ng of $F$. hepatica DNA allows the amplification of the $124 \mathrm{bp}$ probe. This sensitivity level allows the detection of one miracidium, the minimal biological unit that can be found in an infected snail. The DNA probe used in this study is not able to differentiate $F$. hepatica from $F$. gigantica but the latter species has a tropical distribution and has not been discuted in Northern Europe (Torgerson and Claxton, 1999). However, this technique is unable to assess whether full intra-molluscan development (leading to cercarial shedding) takes place or not in a potential host. In the present study specific DNA was detected in exposed $R$. balthica, but the absence of cercarial shedding indicates that the infection was abortive.

The mortality rate for uninfected G. truncatula (7\%) was lower than the $38 \%$ reported in a previous study (Vignoles et al., 2004). Here, mortality rates for $R$. labiata and $R$. balthica reached 4 and 38\%, respectively. The maintenance and breeding of $R$. balthica was particularly difficult and infectivity could not be verified due to the lack of metacercariae.

G. truncatula did not support easily the effects of aestivation (Rondelaud and Morel-Vareille, 1975; Rondelaud, 1994) and, under such conditions, other potential vectors could play an important role in parasite transmission. In Belgium where the three species are present the respective role of each of them remained to be determined although $G$. truncatula is the main intermediate host. However in other European countries where $G$. truncatula is rare or absent, other species belonging to the genus Radix could play a major role in the epidemiology of fasciolosis as already suggest (Boray, 1969; Caron, 2004).

Both G. truncatula and a population of R. labiata were able to produce $F$. hepatica metacercariae under experimental conditions, although at very different levels. In most previous studies on the vectorial capacity of different snail species, the viability and infectivity of metacercariae have not been considered. In the present work, experimental infection of rats with metacercariae produced by either $G$. truncatula or $R$. labiata was performed and no differences were observed between the two groups of rats. The antibody response as measured by ELISA was in agreement with a previous report of experimental infection in rats (Mulcahy et al., 1999). Copro-antigen detection was found to be particularly useful and reliable: faecal samples are easy to obtain and a positive signal is associated with the presence of viable flukes in the bile ducts (Mezo et al., 2004). Furthermore, copro-antigens can be detected before patency.
To summarize the results of the present study, $R$. labiata harboured the intra-molluscan development and allowed subsequent shedding of $F$. hepatica cercariae, although in fairly low numbers. These metacercariae were as infective in a rat as those produced in $G$. truncatula as judged by parasitological and serological data. Therefore, this population of $R$. labiata can be considered as an incidental intermediate host for $F$. hepatica in Belgium and elsewhere. This is probably not the case, however, for this population of $R$. balthica. These laboratory results should be confirmed in the field in naturally-infected potential vectors.

\section{Acknowledgements}

We are deeply indebted to Prof. Maria D. Bargues, Prof. Santiago Mas-Coma, and to Dr. Pablo Artigas who confirmed the DNA-based snail identification. (Parasite and Vector Molecular Analysis Centre of the Department of Parasitology, University of Valencia, Spain). This work was supported by the Faculty of Veterinary Medicine of the University of Liège, Belgium.

\section{References}

Almeyda-Artigas, R.J., Bargues, M.D., Mas-Coma, S., 2000. ITS-2 rDNA sequencing of Gnathostoma species (Nematoda) and elucidation of the species causing human gnathostomiasis in the Americas. J. Parasitol. 86, 537-544.

Altschul, S.F., Madden, T.L., Schaffer, A.A., Zhang, J., Zhang, Z., Miller, W., Lipman, D.J., 1997. Gapped BLAST and PSI-BLAST: a new generation of protein database search programs. Nucl. Acids Res. 25, 3389-3402.

Anderson, T.J.C., 2001. The dangers of using single locus markers in parasite epidemiology: Ascaris as a case study. Trends Parsitol. 17, 183-188.

Augot, D., Rondelaud, D., Dreyfuss, G., Cabaret, J., Bayssade-Dufour, C., Albaret, J.L., 1998. Characterization of Fasciola hepatica redial generations by morphometry and chaetotaxy under experimental conditions. J. Helminthol. 72, 193-198.

Bank, R.A., Bouchet, P., Falkner, G., Gittenberger, E., Hausdorf, B., von Proschwitz, T., Ripken, E.J. 2002. Checklist of species-group taxa of continental Mollusca living in Belgium (CLECOM section I). Göteborgs Naturhistoriska Museum, Göteborgs.

Bargues, M.D., Mas-Coma, S., 1997. Phylogenetic analysis of lymnaeid snails based on 18S rDNA sequences. Mol. Biol. Evol. 14, 569-577.

Bargues, M.D., Mas-Coma, S., 2005. Reviewing lymnaeid vectors of fascioliasis by ribosomal DNA sequence analyses. J. Helminthol. 79, 257-267.

Bargues, M.D., Mangold, A.J., Munoz-Antoli, C., Pointier, J.P., MasComa, S., 1997. SSU rDNA characterization of lymnaeid snails transmitting human fascioliasis in South and Central America. J. Parasitol. 83, 1086-1092.

Bargues, M.D., Horak, P., Patzner, R.A., Pointier, J.P., Jackiewicz, M., Meier-Brook, C., Mas-Coma, S., 2003. Insights into the relationships of Palearctic and Nearctic lymnaeids (Mollusca: Gastro- 
poda) by rDNA ITS-2 sequencing and phylogeny of stagnicoline intermediate host species of Fasciola hepatica. Parasite 10, 243 255.

Bargues, M.D., Vigo, M., Horak, P., Dvorak, J., Patzner, R.A., Pointier, J.P., Jackiewicz, M., Meier-Brook, C., Mas-Coma, S., 2001. European Lymnaeidae (Mollusca: Gastropoda), intermediate hosts of trematodiases, based on nuclear ribosomal DNA ITS-2 sequences. Infect. Genet. Evol. 1, 85-107.

Belfaiza, M., Abrous, M., Rondelaud, D., Moncef, M., Dreyfuss, G., 2004. The use of Tetraphyll ${ }^{\circledR}$ as food for snails increases the intensity of cercarial shedding in Galba truncatula infected with Fasciola hepatica. Parasitol. Res. 94, 86-90.

Boray, J.C., 1969. Experimental fascioliasis in Australia. Adv. Parasitol. 7, 95-210.

Boray, J.C., 1978. The potential impact of exotic Lymnaea spp. on fascioliasis in Australasia. Vet. Parasitol. 4, 127-141.

Boray, J.C., 1982. Fascioliasis. CRC Press, Boca Raton, FL, USA.

Bossaert, K., Jacquinet, E., Saunders, J., Farnir, F., Losson, B., 2000. Cell-mediated immune response in calves to single-dose, trickle, and challenge infections with Fasciola hepatica. Vet. Parasitol. 88, $17-34$.

Busson, P., Busson, D., Rondelaud, D., Pestre-Alexandre, M., 1982. Données expérimentales sur l'infestation des jeunes de cinq espèces de limnées par Fasciola hepatica L. Ann. Parasitol. Hum. Comp. 57, 555-563.

Caron, Y. 2004. Une étude de la faune malacologique associé aux petites surfaces aquatiques en Belgique et évaluation préliminaires par des techniques de biologie moléculaire du rôle potentiel de différentes espèces dans le maintien du cycle de Fasciola hepatica (Trematoda, Linnaeus 1758). Liège, Université de Liège, 35pp.

Carvalho, O.S., Cardoso, P.C., Lira, P.M., Rumi, A., Roche, A., Berne, E., Muller, G., Caldeira, R.L., 2004. The use of the polymerase chain reaction and restriction fragment length polymorphism technique associated with the classical morphology for characterization of Lymnaea columella, L. viatrix, and $L$. diaphana (Mollusca: Lymnaeidae). Mem. Inst. Oswaldo Cruz 99, 503-507.

Cucher, M.A., Carnevale, S., Prepelitchi, L., Labbe, J.H., WisniveskyColli, C., 2006. PCR diagnosis of Fasciola hepatica in fieldcollected Lymnaea columella and Lymnaea viatrix snails. Vet. Parasitol. 137, 74-82.

Dreyfuss, G., Abrous, M., Rondelaud, D., 1997. Fasciola hepatica Linné: la charge rédienne et les émissions cercariennes chez les juvéniles de Lymnaea peregra peregra Müller. Rev. Med. Vet. (Toul.) 148, 609-612.

Dreyfuss, G., Abrous, M., Rondelaud, D., 2000. The susceptibility of Lymnaea fuscus to experimental infection with Fasciola hepatica. J. Parasitol. 86, 158-160.

Genicot, B., Mouligneau, F., Lekeux, P., 1991. Economic and production consequences of liver fluke disease in double-muscled fattening cattle. Zentralbl. Veterinarmed. B 38, 203-208.

Kaplan, R.M., Dame, J.B., Reddy, G.R., Courtney, C.H., 1995. A repetitive DNA probe for the sensitive detection of Fasciola hepatica infected snails. Int. J. Parasitol. 25, 601-610.

Kaplan, R.M., Dame, J.B., Reddy, G.R., Courtney, C.H., 1997. The prevalence of Fasciola hepatica in its snail intermediate host determined by DNA probe assay. Int. J. Parasitol. 27, 15851593.

Kramer, F., Schnieder, T., 1998. Sequence heterogeneity in a repetitive DNA element of Fasciola. Int. J. Parasitol. 28, 1923-1929.

Lonneux, J.F., Boelaert, F., Vandergheynst, D., Biront, P., Meulemans, G., 2000. Fasciola hepatica in Belgium: Survey of the Disease's
Prevalence and Comparison with Previous Simulations. Veterinary and Agrochemical Research Center, pp. 56-57.

Magalhaes, K.G., Passos, L.K., Carvalho Odos, S., 2004. Detection of Lymnaea columella infection by Fasciola hepatica through Multiplex-PCR. Mem. Inst. Oswaldo Cruz 99, 421-424.

Malek, E.A., 1984. Snail Transmitted Parasitic Diseases. CRC Press, Boca Raton, Fl, USA.

Mas-Coma, S., 2005. Epidemiology of fascioliasis in human endemic areas. J. Helminthol. 79, 207-216.

Mas-Coma, S., Bargues, M.D., Valero, M.A., 2005. Fascioliasis and other plant-borne trematode zoonoses. Int. J. Parasitol. 35, 12551278.

Mezo, M., Gonzalez-Warleta, M., Carro, C., Ubeira, F.M., 2004. An ultrasensitive capture ELISA for detection of Fasciola hepatica coproantigens in sheep and cattle using a new monoclonal antibody (MM3). J. Parasitol. 90, 845-852.

Mostafa, O.M., Taha, H.A., Ramadan, G., 2003. Diagnosis of Fasciola gigantica in snail using the polymerase chain reaction (PCR) assay. J. Egypt. Soc. Parasitol. 33, 733-742.

Mulcahy, G., Joyce, P., Dalton, J.P., 1999. Immunology of Fasciola hepatica. In: Dalton, J.P. (Ed.), Fasciolosis. CABI Publishing, Wallingford, Oxon, pp. 341-375.

Ollerenshaw, C.B., 1971. Some observations on the epidemiology of fascioliasis in relation to the timing of molluscicide applications in the control of the disease. Vet. Rec. 88, 152-164.

Pfenninger, M., Cordellier, M., Streit, B., 2006. Comparing the efficacy of morphologic and DNA-based taxonomy in the freshwater gastropod genus Radix (Basommatophora Pulmonata). BMC Evol. Biol. 23, 100.

Preveraud-Sindou, M., Rondelaud, D., 1995. Localization and outcome of Fasciola hepatica sporocysts in Lymnaea truncatula subjected to mono- or plurimiracidial exposure. Parasitol. Res. 81, 265-267.

Rognlie, M.C., Dimke, K.L., Knapp, S.E., 1994. Detection of Fasciola hepatica in infected intermediate hosts using RT-PCR. J. Parasitol. 80, 748-755.

Rondelaud, D., 1993. Variabilité interpopulationnelle de l'infestation fasciolienne chez le mollusque Lymnaea truncatula Müller. Influence du contact préalable de la population avec le parasite. Bull. Soc. Zool. Fr. 118, 185-193.

Rondelaud, D., 1994. Fasciola hepatica: the infection rate and the development of redial generations in Lymnaea truncatula exposed to miracidia after experimental desiccation and activation in water. J. Helminthol. 68, 63-66.

Rondelaud, D., Morel-Vareille, C., 1975. Distribution estivale et survie des Limnées tronquées Lymnaea (Galba) truncatula Muller saines ou infestées par Fasciola hepatica L. Ann. Parasitol. Hum. Comp. 50, 603-616.

Rondelaud, D., Deneve, C., Belfaiza, M., Mekroud, A., Abrous, M., Moncef, M., Dreyfuss, G., 2004. Variability in the prevalence of infection and cercarial production in Galba truncatula raised on a high-quality diet. Parasitol. Res. 92, 242-245.

Shubkin, C.D., White, M.W., Abrahamsen, M.S., Rognlie, M.C., Knapp, S.E., 1992. A nucleic acid-based test for detection of Fasciola hepatica. J. Parasitol. 78, 817-821.

Torgerson, P., Claxton, J., 1999. Epidemiology and control. In: Dalton, J.P. (Ed.), Fasciolosis. CABI Publishing, Wallingford, Oxon, U.K, pp. 113-149.

Van der Steen, W.J., Van den Hoven, N.P., Jager, J.C., 1969. A method for breeding and studying freshwater snails under continuous water change, with some remarks on growth and reproduction in Lymnaea stagnalis. J. Zool. 19, 131-139. 
Vignoles, P., Dreyfuss, G., Rondelaud, D., 2002. Redial growth and cercarial productivity of Fasciola hepatica in three species of young lymnaeid snails. J. Helminthol. 76, 269-272.

Vignoles, P., Menard, A., Rondelaud, D., Chauvin, A., Dreyfuss, G., 2001. Fasciola hepatica: the characteristics of experimental infections in Lymnaea truncatula subjected to miracidia differing in their mammalian origin. Parasitol. Res. 87, 945949.

Vignoles, P., Menard, A., Rondelaud, D., Agoulon, A., Dreyfuss, G., 2004. Fasciola hepatica: the growth and larval productivity of redial generations in Galba truncatula subjected to miracidia differing in their mammalian origin. J. Parasitol. 90, 430-433. 